\title{
The deficiency of dispute settlement mechanism
} seen in Chinese construction field from FIDIC

\author{
Dezhi Li, Huiyan Zhang, and Xuehua Fang
}

Business School of Shenyang Jianzhu (Construction/Engineering)University, Shenyang, China

\begin{abstract}
Since formally introduced the friendly Amicable Settlement mechanism in 1987, FIDIC' $s$ efforts to promote and improve the alternative dispute settlement mechanism for construction work have been greatly developed. The current laws and regulations in China on alternative dispute resolution mechanisms for construction disputes are not perfect, and the newly revised "Conditions of contract for Construction" (GF2017-0201) lacks operability. It is of great significance to improve the dispute settlement mechanism by drawing on the provisions of article 20 of FIDIC (New Red Book), accumulate international experience and develop "One Belt And One Road".
\end{abstract}

\section{Introduction}

The concept of Alternative Dispute Resolution (ADR) originated from the United States and has been gradually developed in the last century for a variety of non-litigation Dispute settlement method which has been extended to the general term of non-litigation dispute settlement procedures or mechanisms which are common in most countries in the world. FIDIC, as a world famous international engineering consulting agency, has been effectively compiling a series of standard contracts for construction projects since its establishment in 1913, and these contracts have been widely used in construction projects around the world. Since the amicable settlement was formally introduced in 1987 and the Dispute Adjudication Board (DAB) introduced in 1999, FIDIC's efforts to promote dispute resolution with ADR mechanisms have never stopped. FIDIC represents globally the 
consulting engineering industry by promoting the business interests of firms supplying technology-based intellectual services for the built and natural environment. FIDIC is particularly well known for its work in drafting standard form conditions of contract which is used on higher value international construction projects, and are endorsed by many multilateral development banks. For example, the Pink Book of FIDIC is intended for projects funded by Multilateral Development Banks, such as the World Bank or the European Bank for Reconstruction and Development.

Now FIDIC is the most commonly accepted and applicable construction project standard contract text in the world, in order to promote the use of FIDIC contract text, to solve the problem of connection between FIDIC and local laws, establishment of a relatively mature alternative dispute resolution mechanism through legal cases and the form of legislation are required. As China's "One Belt And One Road" construction project continues to enter the implementation stage, the establishment of the dispute settlement mechanism should learn more from the mature advanced mode known and accepted by most countries in the world, such as FIDIC, which is applicable to both the domestic project construction and the peripheral cooperative countries of "One Belt And One Road".

\section{The evolution and revelation of alternative dispute resolution in FIDIC}

The development path of alternative dispute resolution mechanism of FIDIC can be summarized as the following stages:

\subsection{The First Stage}

Since its establishment, FIDIC compiled and published the first edition to the third edition of Red Book in 1957, 1969 and 1977. In terms of the design of dispute resolution mechanism, the role of engineer was highly focused, that is, the disputing party should first submit the dispute to the engineer, who will make a decision within a certain period after receiving the submission. If either party is not satisfied with the award or the engineer fails to give the award within the prescribed period, either party to the contract may start the arbitration procedure to resolve the dispute according to the arbitration agreement articles in the contract. .At this stage, the settlement of disputes in FIDIC is relatively simple and monotonous, and the choice of contract parties to resolve dispute is restricted. At the same time, due to the dual responsibilities of the engineer as the agent of the Employer and the supervisor of the project on behalf of the Employer, people are quite confusing whether the engineer can fairly adjudicate the disputes between the Employer and the Contractor.

\subsection{The Second Stage}

In 1987, when prepared and published the fourth edition of the Red Book, in order to avoid the parties' excessive use of costly and time-consuming arbitration procedures, FIDIC 
creatively introduced the terms of Amicable Settlement article as a prerequisite for the parties to apply for arbitration ${ }^{[1]}$. Since the fourth edition of the Red Book came out in 1987, the alternative dispute settlement mechanism has been widely applied and developed in various contract texts, and many institutions have followed the practice of FIDIC, for example, the institution of Civil Engineers in London introduced conciliation procedures in its Minor Works Contract Form, first published in 1988. its success prompted the introduction of such procedures in subsequent forms of contract: the sixth edition of the ICE form and the ICE Design and Construct Contract.

\subsection{The Third Stage}

In 1995, FIDIC began to introduce the Dispute Adjudication Board (DAB) in Orange Book, and added it by way of a supplement to the fourth edition of the Red Book published in 1996.The three major FIDIC Contract templates, such as Red Book 1999, Yellow Book 1999 and Silver Book 1999, use the DAB as the primary means of resolving disputes. ${ }^{[2]}$ The $\mathrm{DAB}$ is a new alternative dispute settlement mechanism advocated by FIDIC to replace DRB ${ }^{[3]}$ It is an alternative dispute settlement method with FIDIC characteristics created by FIDIC on the basis of summarizing previous contract experience and combining with DRB characteristics. Different from DAB, DRB's decision is a suggestion to both parties for dispute resolution, and the parties may or may not execute; While DAB's decision can be enforced by parties who applying for dispute resolution, if not, the non-executive party will face the passive position of arbitration or litigation.

\section{Insufficiency of dispute settlement mechanism of construction project in China}

Now the corresponding articles of ADR have been also stipulated in the standard text of construction contract compiled and implemented by the Ministry of Housing and Urban-Rural Development, Ministry of Water Resources, State Electric Power Company, State Administration for Industry and Commerce and other state administrative departments. For example, the Construction Contract (demonstrative text) (GF2017-0201) (hereinafter

[1] Nael G. Bunni, The FIDIC Forms of Contract third edition, Blackwell Publishing 2005 p439. Article 67.2 of the Red Book (Forth Edition) states: "arbitration cannot be submitted unless both parties have made an attempt to settle the dispute amicably. The attempt shall be made within 56 days and the period of time may be extended by mutual agreement."

${ }^{[2]}$ Nael G. Bunni, The FIDIC Forms of Contract third edition, Blackwell Publishing 2005 pp600,601

${ }^{[3]}$ DRB: Dispute Review Board, ordinarily consists of three experts (one party may be used) who are appointed when a contract is awarded but before disputes arise. Once a dispute arises during the construction of the works, which cannot be resolved at site level or by the conventional mechanisms in the contract, the dispute will be refered to the dispute review board. See Peter Hibberd, Paul Newman,ADR and Adjudication in Construction Disputes.Blackwell first published 1999 pp99-100 
referred to as the ("demonstrative text") formulated and issued by the State Administration for Industry and Commerce, and the Conditions of Contract for Water Resources and Hydropower Construction (demonstrative text) "(hereinafter referred to as the "water and power demonstrative text ") by the Ministry of Water Resources, State Power Company and the State Administration for Industry and Commerce. The former provides ADR mechanism in article 20, but not Amicable settlement provisions provided before submitting arbitration by either party, while the latter provides for the ADR mechanism with Amicable settlement provisions before submitting arbitration in articles 44 and 45 which is if any party holds different opinions on the review of the disputes, further friendly consultations shall be required within 42 days, which is the precondition for the parties to apply for arbitration or litigation.

However, the successful cases by ADR for construction dispute resolutions have not been seen much in practice, or in another words, the relative laws and articles of such standard contracts have not worked well what thought it was. The main reason of such situations is that the government's administrative action is too strong, which have strongly controlled and dominated the alternative dispute settlement mechanism, and the engineers professionals advocated by them did not play a positive and effective role, there are still many problems and deficiencies in the specific operation of the vicarious dispute resolution, which is mainly shown in the following aspects:

\subsection{The dispute settlement method lacks operability}

Article 20 of 2013 edition of "demonstrative text" introduced alternative dispute resolution mechanism which including reconciliation, mediation, demonstrated a great progress than article 37 of 1999 edition. As stipulated, the experts invited by the contract parties may participate in the whole process of Dispute review mechanism and can give separate review opinions, in which will greatly digest the differences in performance of engineering contracts, reduce the difficulty of the contract, prevent obstacles in contract performance, and quickly settle disputes so as to ensure the overall economic and social benefits of the project.

However, compared with the specific content of article 20 of the New Red Book of FIDIC, the "demonstrative text" has no provision of Amicable Settlement as the precondition for dispute review. If the dispute review cannot be accepted by any party, each party can directly apply for arbitration and litigation. There is no 56-day cooling-off period required by FIDIC.At the same time, the "demonstrative text" and "model text of the ministry of water resources" are still inadequate in the following aspects:

(a) there is no specific provision for the appointment of the members of the dispute review board once the parties reach an impasse on the selection and how to break it;

(b) there is no specific provision for the failure of the dispute review board to make a decision within the specified time; 
(c) there is no specific provision on who will pay the remuneration and expenses of the members of the dispute review board and how to pay them;

(d) there is no specific provision on the scope of jurisdiction of the dispute review board and the status of the chief member of the board;

(e) there is no clear provision on the relationship between the dispute review procedures with the arbitration or the court, whether the board members can be arbitrators in the subsequent arbitration proceedings, and whether they will be witnesses to testify in court.

\subsection{The "dispute review" lacks the support of relevant laws and regulations}

China is a country with civil law system, disputes arising from the use of contracts are mainly settled by the provisions of the contract, as well as the contract law, construction law, construction regulations and the judicial interpretation from the Supreme Court of China. But so far, there has been no relevant laws, regulations and judicial interpretation to make the corresponding specification on "demonstrative text" or "water and power demonstrative text " with regard to dispute negotiation, mediation, the dispute review, amicable settlement and other rules of law applicable, which in practice, weakened the perfection and development of alternative dispute settlement mechanism in construction field.

\subsection{The role of engineering consulting professionals is absent}

FIDIC is a no governmental international engineering consulting organization, consulting engineers association plays an indispensable role in the drafting and formulation of the construction contract and the settlement of disputes. ICE, NEC in the UK, and AIA in the US have also developed standard contract texts that apply to their home countries and which have played a good role in resolving disputes. However, the civil engineer association and the supervision engineer association of China did not play their due role in drafting " demonstrative text "and"water and power demonstrative text "and the settlement of disputes. At the same time, the application of " demonstrative text "and"water and power demonstrative text " in practice is not universal, many big investors and developers, such as Wanda, vanke real estate developers only use their own drafted contracts, and while the"demonstrative text" and"water and power demonstrative text " are used only for some projects.

\section{Conclusions}

According to a survey of 589 UK construction professionals conducted by the law firm Masons Solicitors in December 2000, 70 percent of those surveyed said arbitration procedures were fair, prompt and reliable. Ninety percent of respondents thought the program was a quick one. 81 per cent of respondents considered the cost-saving process; According to the experience of mason law firm, the decision of the adjudicator becomes the 
final effective decision in $80 \%$ of cases. ${ }^{[5]}$ That is to say, the ADR mechanism on construction disputes in the western world has played a positive and effective role, and which is also affecting the formation and revision of Chinese construction disputes resolution mechanism, promote the perfection of related system design and legislation in China.

\subsection{Improve the provisions of article 20 of the "demonstrative text"}

If either party of the contract does not agree with the conclusion of the $\mathrm{DAB}$, prior to the submission of arbitration, the setting of a cooling-off period is necessary for the employer or the contractor., and once both parties reach a deadlock on the selection of DAB member, the countermeasures must be seen. Moreover how to break the deadlock; How to deal with the dispute review board's failure to reach a decision within the specified time; Who will pay and how to pay the remuneration and expenses of the DAB members; the scope of jurisdiction of the dispute review board, the position of the lead member of the board, and so on, which should be clearly defined to facilitate operational practice.

\subsection{Improving the formulation and promotion of supporting documents} related to the "demonstrative text" and "water and power demonstrative text"

FIDIC simplify the contract language and develop contract use guides in order to promote the operability of the contract in practice, which greatly facilitates the understanding and mastery of the contract terms by employers and contractors. Therefore, perfection of relevant supporting documents of the " demonstrative text "and "water and power demonstrative text "that are integrated with the contents of them, is the preconditions for popularizing the " demonstrative text "and "water and power demonstrative text ". At the same time, FIDIC interprets the problems and solutions of the latest engineering disputes through conferences and online training every year worldwide, so that FIDIC users can constantly update their understanding of FIDIC, understand and master the latest interpretation of FIDIC, which is what we should learn and learn from.

\subsection{Strengthen the role of the engineer professionals organization in dispute settlement mechanism}

At present, as state-owned enterprises occupy an absolute dominant position in China's construction market, the administrative intervention of government departments has been accompanied by the whole process of the project. When the construction dispute occurs, ADR mainly manifests itself in government mediation and coordination, while the role of supervisory engineers or industrial organizations in dispute resolution is often neglected.This situation does not accord with the prevailing practice in the international

\footnotetext{
${ }^{[5]}$ Zhang lei. An Analysis of Dispute Settlement Procedures For Arbitrators in the field of Construction Engineering, Hebei Law Journal, 7th issue, 2009, cited from Michael Evan Jaffe,Ronan J.Mc Hugh,U.S.Project Disputes; Has the Time to Consider Adjudication Finally Arrived? Dispute Resolution Journal,May-July,2007
} 
engineering field.

Therefore, it is necessary to highlight the leading position of the engineer professionals in the dispute settlement mechanism of construction project, give play to its professional advantages in the field of construction engineering, scientifically design the procedural rules for dispute settlement, and regard the engineer professionals as the organization appointed and selected by the members of the dispute settlement team. Weaken the role of government administrative departments in dispute settlement and strengthen the leading role of industry organizations.

At present, many commercial mediation organizations have established a connection with the courts, which aims to strengthen the role of industrial organizations in the dispute settlement mechanism, for example, the connection between "international commercial mediation center of One Belt And One Road " and Beijing No.4 Intermediate People's Court; The connection between Shanghai economic, trade and commercial mediation center and the People's Courts of Shanghai No.1 and No.2 Intermediate People's Courts and Pudong New Area People's Court; China Council for the Promotion of International Trade/China International Chamber of Commerce Mediation Center and Beijing Xicheng District People's Court, etc.These mechanisms provide a policy and practical basis for the improvement of Construction dispute settlement mechanism. ${ }^{[6]}$

\section{FIDIC}

FIDIC is an acronym for Fédération Internationale Des Ingénieurs Conseils - i.e. the French for the International Federation of Consulting Engineers. FIDIC is well known for its work in drafting standard form conditions of contract which are used on higher value international construction projects, and are endorsed by many multilateral development banks. FIDIC published its first contract, titled "The Form of contract for works of Civil Engineering construction," called red book in 1957. As the title indicated, this first contract was aimed at the Civil Engineering sector and it soon became known for the colour of its cover. After that, the FIDIC published second, third and forth edition of red book, made supplement in 1996 and published new suite of new red book in 1999.

\footnotetext{
${ }^{[6]}$ Gui-xiang liu.Establish a fair, efficient and convenient "One Belt And One Road" cross-border dispute resolution mechanism. China court network.

See:https://www.chinacourt.org/article/detail/2017/09/id/3005632.shtml
} 


\section{References}

1. Nael G. Bunni, The FIDIC Forms of Contract third edition, Blackwell Publishing (2005)

2. Weijia. International Engineering Contract Management (Dual Language). China Construction Industry Press (2010)

3. Li Mingshun. FIDIC Conditions and Contracts Management.Metallurgical Industry Press (2011)

4. The Gudie for Constrction Contract (2013 Official Version) (Revised Edition) . China Construction Industry Press (2013)

5. Brian W.Totterdill. FIDIC User's Guide A Practical Guide for the 1999 Red and Yellow Books. Thomas telford, first published (2006)

6. Cui Jun. Principle and Practice of FIDIC Contract (First edition).Machinery Industry Press (2011)

7. Li Dezhi. Introduction to Fidic Contract Terms(Bilingual).China Construction Industry Press (2017)

8. FIDIC (First Edition 1999) ISBN2-88432-022-9

9. John J. P. KROL. Construction Contract Law. John Wiley\&Sons Inc. (1993)

10. Peter Hibberd, Paul Newman. ADR and Adjudication in Construction Disputes, Wiley-Blackwell (1999)

11. Michael Robinson, A Contractor's Guide to the FIDICC and Conditions of Contract, Wiley (2011)

12. Richard H. Clough. Contruction Contracting, a Practical Guide to Company Management(Seven Edition). John Wiley \& Sons Inc. (2004)

13. John Van Der Ouil, Arjan Van Weele. International Contracting (Contract management in Complex Construction Projects). Imperial College Press. (2014) 